Please do not remove this page

RMIT

UNIVERSITY

\title{
The tourism market's response to the 2009 black Saturday bushfires: The case of Gippsland
}

Walters, Gabrielle; Clulow, Val

https://researchrepository.rmit.edu.au/esploro/outputs/9921859968501341/filesAndLinks?institution=61RMIT_INST\&index=null

Walters, G., \& Clulow, V. (2010). The tourism market's response to the 2009 black Saturday bushfires: The case of Gippsland. Journal of Travel \& Tourism Marketing, 27(8), 844-857.

https://doi.org/10.1080/10548408.2010.527250

Document Version: Accepted Manuscript

Published Version: https://doi.org/10.1080/10548408.2010.527250

Repository homepage: https://researchrepository.rmit.edu.au

(C) Taylor \& Francis Group, LLC

Downloaded On 2023/04/26 20:27:44 +1000

Please do not remove this page 
Thank you for downloading this document from the RMIT Research Repository.

The RMIT Research Repository is an open access database showcasing the research outputs of RMIT University researchers.

RMIT Research Repository: http://researchbank.rmit.edu.au/

\section{Citation:}

Walters, G and Clulow, V 2010, 'The tourism market's response to the 2009 black Saturday bushfires: The case of Gippsland', Journal of Travel \& Tourism Marketing, vol. 27, no. 8, pp. 844-857.

See this record in the RMIT Research Repository at:

http://researchbank.rmit.edu.au/view/rmit:22803

Version: Accepted Manuscript

Copyright Statement: (c) Taylor \& Francis Group, LLC

Link to Published Version:

http://dx.doi.org/10.1080/10548408.2010.527250 


\section{The Tourism Market's response to the 2009 Black Saturday Bushfires: the case of Gippsland}

Running Head: Tourists' response to the Black Saturday Bush Fires

\section{Summary}

The primary aim of the research was to better understand how a large scale disaster impacts upon the tourist's destination image and visitation intentions, and the role of the media. Focus group research reveals the post-disaster media interpretations, images and visitation intentions of intrastate and interstate, regional and metropolitan tourists. Differences are observed in relation to the participants' geographic location and distance from the fires and their understanding of the event, including their reflections on media coverage. Varying perceptions among the participants, of the impact of the fires and the travel risk and subsequent travel intentions to the region, are discussed.

KEYWORDS; Disaster recovery marketing, destination image, media impacts, Black Saturday Bushfires 


\section{ABSTRACT}

One of the key roles of a destination marketing organisation (DMO) is to portray their destination in such a way that it is both appealing and inviting to their existing and potential tourism market. A challenge faced by a DMO in the regional Victorian destination of Gippsland in Australia, is the fact that they also have to manage unanticipated sudden changes in market perceptions that may occur in response to a disastrous event. The reoccurring natural disasters of this region (fires, floods and drought) - the most recent being the 2009 Black Saturday Bushfires, deemed Australia's worst natural disaster in history, make it imperative that DMOs can respond effectively. This paper presents the findings of an exploratory research project designed to investigate the tourism market's response to this particular disastrous event. The primary aim of the research was to better understand how a large scale disaster impacts upon the tourist's destination image and visitation intentions, and the role of the media in these deliberations. Focus group research reveals the post-disaster media interpretations, images and visitation intentions of intrastate and interstate, regional and metropolitan tourists. Differences are observed in relation to the participants' geographic location and distance from the fires and their understandings of the event, including their reflections on media coverage. Varying perceptions among the participants, of the impact of the fires, the travel risk and subsequent travel intentions are discussed. Managerial implications relating to media management and the refinement of future disaster management strategies are also presented.

KEYWORDS. Disaster recovery marketing, destination image, media interpretation, Black Saturday Bushfires

\section{INTRODUCTION}

\section{GIPPSLAND AND THE 2009 BLACK SATURDAY BUSHFIRES}

The February 2009 Black Saturday bushfires have been defined as Australia's worst natural disaster ever, with as many as 400 individual fires burning across the state of Victoria on the one day. It is estimated that these fires destroyed in excess of 3500 structures, over 200 lives and displaced more than 7500 people. A total of 78 towns throughout the state were affected, many of which had a high dependency on tourism.

Gippsland, located in South East Victoria (see Figure 1) positions itself as one of Victoria's primary nature-based destinations and plays host to a number of internationally recognised nature-based attractions. These natural attractions require the support of local tourism industry stakeholders to accommodate, entertain and attract both national and international visitors. Gippsland's tourism industry is dominated by small family-owned 
businesses and its recognition for being a lucrative and viable industry for Gippsland is demonstrated by its annual local economic contribution of AUD\$688 million (Tourism Victoria, 2007). Despite the fact that only a comparatively small proportion of the region (2.5\%) was affected by the events of Black Saturday, the 2009 Bushfires presented Gippsland's tourism industry with an estimated income loss in excess of \$44 million. Much of this loss was attributed to a steep decline in visitor numbers and a steady stream of cancellations of present and future reservations, as far as 12 months in advance (Destination Gippsland Ltd, 2009). The main areas affected by the fires were Churchill, a small township located in the Latrobe Valley shire, and Wilson's Promontory, one of Gippsland's leading nature based tourism sites.

\section{Insert Figure 1 here}

The Churchill fires were deliberately lit by an arsonist, who on a $46^{\circ}$ (Celsius) total fire ban day, ignited a fire in a pine plantation one kilometre south east of Churchill at approximately $1: 30 \mathrm{pm}$. By late afternoon the fire travelled south-east towards the South Gippsland coastline and as a result of a strong wind change travelled in a north-easterly direction, destroying 57 homes and 11 lives that stood in its path. Five hundred people were evacuated to the nearby township of Traralgon in the shire's Latrobe Valley (Jackson, 2009). Two days later, the Churchill fires were still burning out of control through the Latrobe Valley area and the neighbouring Strzelecki and Jeeralang ranges, destroying a total of 323 square kilometres of bush land, nature reserves and properties (Australian Broadcasting Commission, 2009).

The Wilson's Promontory fire was lit by a lightning strike on the day after Black Saturday. This bushfire, driven by winds of up 70 kilometres per hour, burnt 25200 ha over five weeks, which was close to $50 \%$ of the national park. Wilson's promontory is one of Victoria's signature national parks. Positioned at the southern most point of the Australian mainland, the park hosts the largest coastal wilderness area in Victoria (Parks Victoria, 2009). Campers and lodgers were evacuated from the park at the time of the fires and the park remained closed for 41 days.

The call for this research was prompted by a distinct lack of knowledge among the Gippsland tourism industry about how Gippsland and its national parks were positioned in the minds of the tourists in the wake of the 2009 bushfires. Gippsland presents an interesting and unique context for this research due to its classification as a destination likely to experience recurring disasters (Destination Gippsland Ltd, 2009) and its location within Victoria - formerly identified as 'one of the most bushfire-prone places on Earth' (Parks Victoria and DSE, 2007: 29). Previous investigations into the impact of natural disasters on tourism destinations per se, have included, the impact on the destination and its stakeholders (Cioccio \& Michael, 2007; Roman, 2008) commentary on the destination's response and recovery efforts (Armstrong \& Ritchie, 2007; Ritchie, 2008) and disaster 
management (Blackman \& Ritchie, 2007), however the literature remains relatively scarce. In particular there is a dearth of information on how a destination's tourism market is likely to respond when a familiar tourist destination is struck by disaster. Prideau, Coghlan and Falco-Mammone (2007) claim that while one may be able to broadly predict likely disasters via observable trends such as weather patterns and similar historical events, the impact on industries such as tourism can only be assessed on a case by case basis. The authors suggest that the compilation of case studies that record the tourism market's behavioural responses is one method of establishing precedents that advocate how destination marketers can respond to disastrous events. . Ritchie (2008) supports this position claiming that knowledge from previous disasters can assist in the development of effective prevention and readiness strategies for future events. Carlson and Hughes (2007) suggest that a better understanding of market trends likely to emerge after a disastrous event can provide a more realistic picture of the market oriented responses and opportunities for destinations post-disaster.

\section{DISASTROUS EVENTS AND DESTINATION IMAGE}

Mass tourism has been impacted by crises and disasters for nearly five decades and almost no tourism destination can be fully exempt from disaster (Beirman, 2006). Faulkner (2001)_ defines a tourism disaster as a situation in which "a tourism destination is confronted with sudden, unpredictable, catastrophic changes over which it has little control"(p136). The management of negative destination brand associations that can occur as a consequence of tourism disasters represents a significant challenge for tourism destination marketers (Lehto, Douglas and Park, 2007) and critical to their success, is an understanding of the intervening effect that disasters have on the tourist's destination image formation.

Tourist destination image is defined by Crompton $(1979, \mathrm{p} 408)$ as "the sum of beliefs, ideas and impressions that a person has of a destination". The importance of a tourist's destination image is universally acknowledged given its influence on the tourist's decision process and ultimately their destination choice (Pearlman and Melnik, 2008; Chon, 1991; Baloglu and McCleary; 1999; Jenkins, 1999; Mayo, 1975; Leisen 2001) and visitation likelihood (Lepp and Gibson, 2003). According to Leisen (2001) the tourist creates an image by collecting and processing information about a destination over time. This information is eventually organised into a mental construct that in some way becomes meaningful to the individual. In effect, reality becomes secondary as the tourist's perceptions prevail in consideration of their destination choice (Guthrie and Gale, 1991).

From a marketing perspective, information sources such as the mass media are viewed as an external stimulus likely to influence image formation. For example, Beirman, (2003) argues that whilst the mass media's role is to generate awareness, it also holds significant power in relation to the shaping of perceptions not only about the extent of a disastrous 
event, but also about the destination in which in the event takes place. Further, the impact can be moderated over time by the phenomenon known as issue-attention (Hall, 2002), where there is often a wane in coverage of a disaster, by the media and by politicians.

According to Armstrong \& Ritchie (2007) the global availability of media can rapidly lead to the formation of negative perceptions of a disaster affected destination. Given the global nature of the tourism product, those regions hit by disasters are likely to experience significant issues related to the destination's marketability. Pearlman and Melnik (2008) for example report on the lasting undesirable effect the media coverage had on New Orleans' tourism industry in the wake of Hurricane Katrina which consequently resulted in the closing of over 1400 tourism related businesses. The 2004 Tsunami that hit Indonesia, Thailand and other nations that border the Indian Ocean generated vast amounts of sensationalised media coverage that focused on the death and destruction that resulted in a significant downturn in tourist arrivals (Prideaux et al, 2007). As Huang, Tseng and Petrick (2007) claim, the mass media can cause a significant level of unwarranted anxiety among potential travellers as media-reliant tourists tend not to independently evaluate the reality behind such reporting of an event. It is critical for destination marketing organisations to understand the tourist's media usage and interpretation when a disaster occurs.

\section{PURPOSE}

Using the Gippsland region and the 2009 Black Saturday Bushfires as the context, this research aims to investigate the tourism market's response to three key concerns-

- media interpretation

- post disaster destination image and

- visitation intentions during and after the fires.

The incorporation of four distinct visitor markets in the study - inter and intrastate and metropolitan and regional - differentiates this research and extends the design of the study to explore the influence of factors such as geographical proximity, past experience and knowledge of the event, via different media sources on the tourists' responses to the 2009 disaster.

\section{METHODOLOGY}

Project design: Because the research is exploratory in nature and theoretically little is known about the topic in question, focus groups were considered to be the best possible approach. Four focus groups were conducted to explore the areas of interest to this research. According to Marshall and Rossman (1995) one of the prime advantages of focus groups is that the format allows the researcher to further explore unanticipated issues as 
they arise in the discussion. The focus group method also allows the researcher to easily assess the extent to which the views of participants are relatively consistent both within a group and between groups (Patton, 1999). Given that the research focus encompassed a topic area that was surrounded by a certain degree of social trauma, it was also deemed to be important to allow the participants to narrate and describe their recollections of the bushfires and consequent opinions in their own terms.

One of the most common criticisms directed towards focus group methods, particularly within the marketing literature, is the small sample sizes which in turn lead to doubts regarding validity (Reed and Payton, 1997). However, as Reissman (2002) warns, a more structured research inquiry open to larger sample sizes can sometimes interrupt and 'fracture' the story telling of experiences to agree with the expected outcomes anticipated by the researcher.

Morgan (1996) cites, whilst individual interviews can be a more effective means for generating ideas and surveys are certainly a more effective method for determining the extent of any given attitude or experience (Ward, Berntrand and Brown, 1992), a unique strength of focus groups lies in their ability to provide insight into the extent of consensus and diversity among a group of people. Via 'the group effect', a focus group discussion allows the researcher to observe the interactions between participants as they query and explain their views to each other which consequently exhibits the amount of consensus among the group. This was of particular importance to the current research given its comparative nature.

Locations: The focus groups took place in Melbourne, Regional Victoria (Geelong), Sydney and Country NSW(Wagga). Interstate (metropolitan and regional) and intrastate (metropolitan and regional) areas were included as the researchers wished to determine if there were differences among the four geographically defined market segments. This sampling design offers two basic advantages. First, it builds a comparative element into the research project, which in the case of the current study was essential to the goals and objectives of the research. Second, segmenting or categorising participants can better facilitate discussions as participants are more alike and less likely to express differing points of view (Morgan, 1996; Tynan \& Drayton, 1988). To ensure a high level of comparability across the four groups, a standardised research design was employed (Morgan, (1996). Whilst Orosz (1994) criticises that the use of identical question schedules across a number of focus groups defies the key tenets of qualitative research, Morgan (1996) argues that method-based decisions should be based on the goals of the particular research as opposed to past tradition. The researchers were therefore confident about their chosen research design.

Sample frame: Destination Gippsland's consumer database was used as the sampling pool from which the participants were recruited. Those listed on the data base were identified as 
tourists who have an interest in and / or are likely to visit Gippsland for tourism purposes. An email was sent to the 2000 people listed on the database seeking expressions of interest and a total of 160 people responded, from which 31 participants were recruited. The regional locations were determined by the number of responses from a particular area, the most represented regions being South West Victoria and NSW's Riverina Region. Nine people participated in the Melbourne session, 6 in the Sydney session, 8 in the Riverina session (Wagga) and 8 in the South West Victoria(Geelong) session.

Data collection: The number of participants in each group was consistent with Krueger and Casey's (2000) recommendation of between six and ten participants. Gender and age categories were generally well represented in the groups, although the Melbourne group was dominated by people aged over 40 . The average length of the sessions was ninety minutes. Participants were reimbursed for their travel and any other expenses incurred as a result of their participation each receiving a maximum of $\$ 70$. The sessions took place at purpose built meeting facilities centrally located at each of the four locations. All four sessions were facilitated by the primary researcher. Ethical clearance was sought and received to conduct the research.

The focus group sessions were recorded and transcribed by a professional transcription agency. According to Robson (1993) the central aim of data analysis is data reduction. The data analysis process therefore began with examining and categorising the four transcripts in alignment with the themes central to the study's objectives. The basis for establishing these themes was taken from a review of related tourism literature in combination with industry needs.

\section{Data Analysis}

To ensure the minimisation of potential bias often associated with the analysis and interpretation of focus group data, Krueger and Casey (2000) recommend that the analysis be systematic, sequential, verifiable and continuous. Lincoln and Guba (1989) agree that following this path can strengthen the dependability, conformity and consistency of the data. The researchers adopted Krueger and Casey's recommendations and the data were therefore subjected to the following process.

A systematic approach to the analysis of large files of text data from focus groups is essential, to providing a transparent evidence trail of the process used for the selection of representative quotations, a fair mix of participants and the identification of views that fall outside the mainstream on the discussion. According to Rabiee (2004, p657), such an approach allows for verification of findings, '...safeguards against selective perception and increases the rigour of the study'. The sequential process outlined here, ensures a verifiable record of each continuous step. Each focus group transcript, with every line of text numbered, and each quotation coded to indicate the participant, was first analysed 
separately. Representative quotations that best captured the group's perception of the issue were copied and pasted by geographic source, into the data file, including the line numbers and participant code from the original transcript. All line numbers and participant codes were retained and included in the final presentation of data indicating their source from the original transcript.

A second revision of selections was made, due to the large body of data first selected. The same process was repeated, of selecting, copying and bolding before pasting into the final draft file. Again a trail of evidence is available in this systematic, sequential approach. The final refinement of data requires a further data reduction, achieved by comparing and contrasting similar quotations (Rabiee, 2004), capturing representative examples, excluding any text that does not add to the representation of the group's narrative story and interpreting the key aspects of most importance to each group. This stage, described by Ritchie and Spencer (1994) as indexing, captures the essence of systematic focus group analysis, the '...sifting the data, highlighting and sorting out quotes and making comparisons both within and between cases' (Rabiee, 2004, p657).

The focus group data will be presented within the themes designated in the research design.

\section{DATA PRESENTATION: FOCUS GROUP THEMES}

Media Interpretation

The media usage by participants during the event included all main media sources across the four focus groups. However media usage did vary between the interstate and intrastate groups. In Sydney, participants referred mostly to newspapers and television as the source for their information, with one participant actively seeking information from the Internet. In regional NSW, people turned to Melbourne Newspapers and Television, and the Country Fire Authority (CFA) Website for their information.

Prior to investigating the tourist's interpretation of the media coverage of the event, it was considered important to gain an understanding of their perceived credibility of the media at the time of fires. Participants were prompted during the focus group session to indicate the level of trust they have in the media - talking especially about the reporting of the 2009 Bushfires. The responses were similar across the four locations with many participants agreeing that the initial reporting (first 48 hours) was considered responsible and trustworthy.

As time went on, intrastate tourists felt that the media started to sensationalise the events as illustrated in the following comments: 
... the first 48 hours were impressive reporting but then it was over kill and by the end of the first week I couldn't watch it anymore on TV or listen to it on the radio, I had to leave the room because they were dwelling on the injuries and the loss of life just more than, more than was necessary really and I just couldn't take it anymore, I would just burst into tears and I'd have to, I can't watch this anymore, I'd just had enough, I was filled with it all, but I think in the beginning they did a wonderful job (Melbourne -W: 342-350).

I think as it is happening, I relied on it that was my sole knowledge. Then once the tragedy had been broadcast I just felt that they were grandstanding and taking advantage and I really didn't want to watch it any more (Regional Vic -C: 277-280)

According to Volo (2007) exaggerated and sensationalised reporting is commonplace and the impact on the tourism market is frequently out of proportion to the nature and extent of the actual damage caused. The comments among the intrastate participants regarding the sensationalism of the media demonstrate that they were in fact conscious of the media's propensity to prolong a disaster's intensity unnecessarily. The following comment from a regional interstate participant also signifies this opinion:

...the commercial networks seemed to sensationalise what they were saying and I noticed after a while that they just kept repeating the 'best' scenes over and over again (Regional NSW - G: 443-446)

Sydney participants commented that much of the information after the initial 48 hour period was both inconsistent and inaccurate across the various media sources, the common theme being a lack of information. There was general agreement within this group that they were not getting the entire story and the media was just giving them a concentrated view of the event - leaving critical elements out. These perceived gaps created a need within one respondent to seek information first hand from friends and relatives who live in Victoria as demonstrated by the following extract:

... But it's just not a true picture in the sense that a lot of bits are missed out; it's just the sort of very concentrated view that we get, so that's my general feeling and I think that's why I also after the fires, I wanted to know, well hang on, now what really is happening down there, what is really going on, I wanted to ring my friends and say well exactly where is it and how bad is it cause I didn't really trust fully that I was getting the whole picture.... (Sydney-C: 283290)

Given the context of the research, the focus group participants were asked to recall any news they had heard about the Gippsland region in the media coverage of the fires and 
many could not recall anything about Gippsland specifically. In Sydney, participants were hazy about Gippsland's boundaries and were not able to name any of the affected townships:

I think it was Gippsland but they didn't name the suburbs so when I heard the suburbs I knew what they were talking about but I didn't go oh those suburbs are Gippsland, I just knew the Victorian bush area and they named the suburb which I was, became familiar with, yet which I've forgotten now but I didn't think that was part of the Gippsland area (Sydney -M: 177-182)

One regional NSW participant was able to recall Wilson's Promontory being affected, but again much of the focus in the media according to this group was the state of Victoria as opposed to specific regions.

...sure Wilsons Promontory was mentioned, but I don't ever remember people saying that fires are raging through Gippsland or that particular area and I think a lot of people have got the idea that, whilst Gippsland boasts mountains, it's on the coastline and you don't expect the fires to be on the coastline as much as you can see them inland, forested areas and the like, so I don't believe I once heard the word Gippsland used in connection with those bush fires. (Regional NSW - G: 386-394)

Regional Victoria participants were only able to recall the criminal investigation that surrounded the deliberately lit Gippsland fires, but they were able to recall specific town ships in Victoria that were affected, unlike NSW participants who had a broader understanding of where the fires were. Melbourne participants were able to make the most direct associations in terms of the exact locations and regions affected by the fires, and two participants spoke of Churchill and Wilsons Promontory. There was consensus however among the group that the Gippsland fires were somewhat overshadowed by areas that experienced significant loss of life, property land and wildlife:

I suppose there wasn't much coverage on the Gippsland fires as they were overshadowed. Fires in Gippsland were not really reported by local radio, after the fire it (Gippsland) got coverage but was again overshadowed by loss of life in King Lake and Marysville and places like that. Other areas were worse off (Melbourne -M: 200-205)

One of the key findings in relation to the use of media in this study was the differences in the level of information and level of understanding in relation to the geographical proximity of the fires. This can potentially explain the NSW market's misconception as to where the fires actually took place and consequently their perceptions of the region in its entirety. Glaesser (2006) refers to this particular effect as the 'distance hypothesis', according to 
which geographical references to a destination become more facetted the closer it is. Support for this assumption was demonstrated by the unanimous decision by Sydney participants not to visit Gippsland at the time of the fires, despite the fact that only a few areas were affected. This is discussed later in the paper.

Regarding participants' media usage and interpretation, three key issues were raised. First, the level of information and understanding of the exact location of the fires appears to become blurred as the tourist's geographical proximity to the event increases. Second, with the exception of the initial 48 hours of media coverage of the event, the level of trust in the media among the all participants was low - with some claiming it was over sensationalised and others (particularly those interstate) claiming there was a lack of information. Finally, despite the extent of damage and loss that occurred in the Gippsland region of Victoria, the bushfire events in surrounding Victorian regions such as Marysville and King Lake overshadowed the news of the Gippsland fires. The latter two findings may explain the surprisingly positive findings related to the Gippsland tourists' subsequent destination image, as discussed in the following section.

\section{Destination Image}

It is becoming increasingly accepted that natural and man-made disasters have a devastating effect on the tourism industry with weakened or negative destination images often being a direct consequence of these events (Lehto et al, 2007). Previous studies by Pearlman and Melnik (2007), Scott, Laws and Prideaux (2007), Armstrong \& Ritchie (2007) and Beirman (2003), have all presented scenarios where destinations have struggled to overcome prevailing destination images that have emerged as a result of an unforeseen disaster.

To explore the image perceptions currently held by the Gippsland tourism market, participants were asked to describe how they feel about Gippsland as a tourism destination. This question was purposefully left until relatively late in the interview as it was anticipated that by this stage the participants would have had enough reflection on their thoughts and memories of the Gippsland fires to provide a valid representation of their resultant feelings towards the region.

A large number of participants across the four groups gave reference to the destination's diversity. Many from Melbourne described Gippsland as being scenic, accessible and offering a range of activity.

I'm impressed with the range of activity and that beauty thing, it's more than just the scenery, it's like in close proximity you've got a completely wide cross section of Australia in Gippsland, other than the desert type area, it's 
certainly got a lot to offer and it's close and accessible (Melbourne - L: 12511255).

Regional NSW participants also commented on the destination's natural beauty and scenery while those from Sydney were also very complementary towards the destination:

I think it's got the best features, it's beautiful and really lovely rural scenery, I love the green rolling hills, driving through there, the scenic drives it's just, they're just really very relaxing and you know there's something new to see around every corner, I love it, the art trails are just really interesting and the food, the food is fantastic there, and you know the best bush walking I have ever done (Sydney-C: 632 -639)

Regional Victorian participants favoured the coastal regions of Gippsland, describing them as peaceful, pristine and isolated and emphasised the 'country experience'. Interestingly, across all four groups there was not one mention by the participants of fire damage or ruin, when they were asked to talk how they feel about Gippsland, suggesting that the events of Black Saturday had little impact on their destination image.

In contrast to the previous research, , these findings are consistent with those of Prideaux et al, (2007) whose study that investigated visitor expectations of a disaster struck destination found little to no change in terms of tourists' expectations of the main attractors of the region post disaster. Gippsland is home to 12 of Victoria's national parks, all of which form the basis of the region's nature-based tourism product (Destination Gippsland, 2009). However, despite the wide spread news regarding the burning of one of Gippsland's most popular natural attractions, (Wilson's Promontory), the participants still referred to the region's scenic natural resources as if nothing had changed or been touched by the fires. Further explanation for this response is offered by Gross and Peterson, (1987) who discuss the compensatory attitudes of consumers, claiming that a negative attribute of one product can often offset the positive attitudes of another. This is particularly relevant to the multifaceted tourism product. For example- the lack of five star accommodation in a location can be offset by the appeal of the natural surrounds, therefore resulting in a favourable attitude overall. In the current context, Gippsland's diverse product offering may be powerful enough to overcome the negative image associations often linked with disastrous events. Support is also revealed for Morrison's (2003) claim that touristic images are resistant to change and relatively persistent over time.

A particular 'image' concern held by the Gippsland's DMO in the wake of the bushfires was the level of risk their tourist market associated with visiting the destination and how safe they perceived the destination to be. In addition to the Black Saturday fires, the past five years have presented Gippsland with a number of large scale disasters, namely floods, 
drought and bushfires. Information was sought to update our view on how tourists rated this destination as a 'safe' holiday option.

In response to the question "Do you believe that Gippsland is a safe place to visit" there was no sense that participants felt in any way threatened by natural or any other kind of disaster in the region. The citation below from a regional Victorian participant exemplifies the kinds of responses that emerged from both interstate and intrastate participants:

I don't think of it as safe or unsafe. It is not something that I really think about, to be honest. It is not one of those things that comes to mind I suppose. But if you are talking about going to the mountains in Peru, I would be worried about guerrilla attacks. I wouldn't be thinking about Gippsland as, "Oh my God, I am going to get burned and washed away". So it is not something that would really come to my mind if I was thinking about it (Regional Vic -C: 701-708).

This comment, among others, indicated to the researchers that the Black Saturday bushfires had seemingly no influence on the tourism market's perceptions of the safety of the destination. Across the tourism literature, there is a general acceptance that perceived safety has a significant influence on the tourist's destination image formation (Sonmez and Graefe, 1998, Hall, Timothy and Duval, 2003; Crompton, 1979; Gartner and Hunt, 1987). The current research suggests that in the case of Gippsland, the 2009 Black Saturday Bushfires has had minimal impact on the region's destination image or its reputation as a safe place to visit. However, given recent claims that risk perceptions related to safety can predict travel intention (Floyd, Gibson, Pennington-Gray and Thapa, 2001), the researchers were also interested in the tourists' willingness to travel to Gippsland at the time of or soon after the bushfires.

Intentions to Travel

As previously mentioned, Gippsland's tourism industry suffered significant financial loss in the wake of the 2009 bushfires, most of which was put down to a steep decline in visitor numbers. Cancellations and a decline in visitation are described as two of the major symptoms of financial loss in the tourism sector when a destination is struck by disaster (Beirman, 2003; Glaesser, 2006; Huang et al., 2007). Examining the reasons why a service or a destination suffers loss of business post disaster can assist destination managers to understand one of the key challenges they face in the wake of a critical event (Scott et al. 2007).

To gain an appreciation of the tourism markets' travel intentions on news of the disaster a hypothetical question was put forward to each group. The participants were asked if they had planned to travel to Gippsland at the time of the fires would they have still travelled to 
the region, cancelled and gone elsewhere or postponed their travel to a later date. The responses across the four groups varied significantly with those that live in the regional areas being more prepared to go ahead with their plans, if possible, than those in the metropolitan areas.

It was unanimous within the Sydney group that visiting the Gippsland region at the time of the fires was not an option. One participant however felt the need to help those in the fire affected region:

I didn't want to go to Gippsland, I just didn't, I, it stops there and I did not want to go and then about three days later on the TV coverage they started saying we need you to come and visit, you know, we need people to come and then I sort of thought oh actually now I feel like I have to go (Sydney-S: 252-257)

There was a common belief among the Melbourne group that they would be in the way, intruding on local residents who were preoccupied with the recovery process:

I'd have cancelled, yeah I'd go somewhere else, as for going there again, I went up to the Macedon on that Ash Wednesday, few days later and while I was up there I realised that you shouldn't be up there, they don't want you you're no help, you're a hindrance, just, the shops don't want to serve you, they've all got things to do, you're a pest, so, you don't go (Melbourne, T: 535-540)

This comment from a Melbourne participant is demonstrative of Lehto et al's (2007) finding that a visitor's anticipation of an overwhelming recovery process can often deter their intention to re-patronise a destination. As is the following comment from the same group:

Cancel it at that time because people had other things on their mind at that time, I mean they didn't need to have extra people around there (Melbourne - L: 411-414).

Regional Victorian participants were generally prepared to still go ahead with the travel plans after seeking advice as to whether it was safe to visit. Only one participant stated they would not visit the region due to the fear of their young children being exposed to the devastation surrounding the fires and the fires themselves. One participant actually did visit the destination very soon after the fires and was able to reflect on their experience:

We did have a holiday booked to Wilsons Promontory and we still did go. I think it was about 24 February, which was just a couple of weeks after the main part of it. We did ring up and just check that the area wasn't affected by bushfires, that the accommodation was still okay because we knew there were fires at Wilsons Promontory and they assured us that everything was 
fine and we still went and had our four days and it was really good (Regional Vic - C: 412-421)

Regional Victorians were also driven by a need to support the tourism industry:

I wouldn't have gone out to make sure they were still standing basically but I would go because I remember seeing a lot on the news of businesses saying, "People, please people still come, we will lose our businesses as well as all our loss from the bushfires". So I would want to support their business and I would still go (Regional Vic -M:404-409)

Participants from regional NSW were quite accepting of bushfires being a normal part of the Australian landscape and experience, and so were very open to the likelihood that they would go ahead with travel plans

...If I was going for a holiday and the facilities were there I can't be thinking oh gosh if I go to Omeo I'm going to have the possibility of bush fires here, I've lived on the land, we've had bush fires come right up to our back door and we just accept it (Regional NSW-S: 649-653)

This latter quotation lends support to previous research by Menfredo, Fishbein, Hass et al (1990) whose study suggested that direct experience with fire along with residency in rural areas can contribute to increased knowledge and heightened tolerance of fire. Further, past experience with such events has also been found to play an intervening role between news of an event and attitude formation towards the affected destination (Kroeber-Riel (1992, as sited in Glaesser, 2006).

There appears to be a polarisation between metropolitan and regional responses to this question. Both regional groups, regardless of their proximity to the fires, were more prepared to visit the Gippsland region at the time of or soon after the events of Black Saturday, whilst the metropolitan groups appeared to display a greater degree of reluctance. The motives or drivers for visiting, the fire affected region at the time of or soon after the event however did provide some insight into the reasons behind their choice. For example, those from Melbourne were not enticed to visit the region as they felt they would be in the way of those in recovery, regional Victorian's were motivated to visit the region to help the industry recover and those in regional NSW would still visit the region as a result of their familiarity with such events. Sydney participants on the other hand were quite unanimous in their decision not to visit the destination. Again the distance hypothesis may offer some explanation for the latter group's decision not to travel, that is, their tendency to regionalise the event may have resulted in their assuming that the whole of Victoria was essentially a 'no go' zone.

\section{CONCLUSIONS}


The aim of the focus group sessions was to examine the tourists' responses to the 2009 bushfires. Using four distinct geographical markets this research has identified the tourists' interpretation, their subsequent destination image and intentions to travel to Gippsland at the time of or soon after the event, of each group. The findings suggest that despite the devastating impact this disaster had on the Gippsland tourism industry, their tourism market remains relatively loyal to the destination and their perceptions are unscathed. However, distinctions are made between the four geographical locations in terms of the participants' interpretation of events and their travel intentions, which in turn offer a number of valuable implications for the tourism industry and those responsible for promoting the destination in the wake of a disastrous event.

It has been implied that media coverage of a disastrous event has a significant impact on the tourist's perceptions of the destination (Pearlman and Melnik, 2007; Prideaux et al, 2007). Whilst the current research did not aim to empirically test this association it did present a detailed account of the tourist's interpretation of the media both during and after the events of Black Saturday. Overall, while participants' perceptions of the locations and severity of bushfires were clearly influenced by the media they attended to, there was not a sense that people were conscientiously seeking information about the situation. Further, the underreporting of the Gippsland fires as a result of the media's focus on the bushfire events in surrounding Victorian regions may potentially explain their maintained positive perceptions of the region. One of the key findings about media interpretations in this study however, was the distance effect demonstrated by those in Sydney, who, as a result of their misperceptions regarding the exact locations of the fires, were somewhat averse to visiting the region's non-affected areas at the time of or soon after the event. To counter this effect, it is recommended that destination marketers provide concise information regarding the exact locality of the disaster affected areas and remain honest in their communications regarding suitability for tourist activity. As Glaesser (2006) claims, increasing distance from a disaster affected destination can be disadvantageous. If negative events are not precisely geographically defined, neighbouring regions who were not affected by the events can also suffer the negative consequences of those directly impacted. DMO's, particularly when planning to communicate with their interstate and overseas markets, need to ensure that the media disassociates the specific towns they want to promote from the fire affected areas and encourage media to name townships as opposed to regions when reporting on fires or other disasters.

Contrary to previous research surrounding disaster recovery marketing (see for example; Sanders, Laing and Houghton, 2008; Lehto, Douglas \& Park,2007; Ritchie and Armstrong, 2007) this study suggests that this particular disaster had little impact on the tourism market's perceptions of Gippsland, with most participants describing the nature-based destination as if it were untouched. This result however must be treated with caution and consideration needs to be given to the fact that most of those who participated in the focus 
groups had yet to return to the destination. It is recommended that while a DMO should remain honest about the state of the region throughout their post disaster marketing campaigns, DMO's should also focus on the main attractors that were not affected by the fires in a bid to reaffirm people's positive perceptions. Another marketing strategy that has been used to promote other Victorian fire affected destinations, such as the Grampians fires in 2006/7, focuses on the beauty of the regenerating landscape. According to Sanders et al., (2008) this marketing message leveraged off the public's curiosity towards the regrowth of burnt areas. Given Gippsland's nature-based product, this approach is also recommended to encourage visitation once regeneration commences.

The willingness of some participants to visit the region during or soon after the fires is supportive of Carlsen and Liburd's (2007) argument that destinations should be promoted during a crisis. The current research suggests that a one size fits all marketing approach is far from adequate and a targeted marketing strategy is essential when promoting a destination believed to be in crisis. The findings indicated that Sydney residents were generally not willing to visit the region at the time of the fires and it was assumed that this could be explained by their lack of knowledge of the exact locations of the fires. Therefore, when targeting the interstate market, the region's DMO should refer to the non-affected areas by their town names as opposed to promoting them under the region's umbrella brand. By disassociating the non- affected areas within the region presumed to be ablaze, the DMO is assisting neighbouring towns unaffected by the disaster to avoid the unnecessary losses that often occur as a result of their brand association with the region (Glaesser, 2006).

The strong empathetic theme that emerged from the regional focus groups suggests that DMO's should initially target regional segments that are motivated to visit a disaster affected destination by the need to support and assist the recovery process, where that is practical in terms of tourist operations and infrastructure. It is recommended that an 'open for business' style campaign with an empathetic style message that portrays the community as being ready and willing to receive visitors be employed. The literature indicates that marketing responses that inform tourists of the region being open for business and which focuses on positive outcomes such as community spirit, restoration and limited loss of attractions, can help to limit the contagion effect of a disaster by providing a clear message for the tourism industry (Hystad and Keller,2008). Honesty and openness about the general state of the destination are also important elements of any recovery marketing campaign as they are said to assist in the eradication of any misconceptions created by the media and help the destination to establish a reputation for reliability and trust among its intended tourism market (Armstrong and Ritchie, 2007; Beirman, 2006).

In summary, this research has provided insight into the perceptions held by the Gippsland tourism market in the wake of the 2009 Black Saturday bushfires. The findings revealed in 
the study have contributed to the tourism literature and presented practical implications in relation to post disaster perceptions and suggestions for recovery marketing. Cross application of the findings however should be regarded with caution, as the focus groups were specifically conducted to examine the Australian tourism market's response to 2009 Black Saturday bushfires. Care also needs to be taken in the generalising these findings given the targeted nature of the study.

Future research is needed to reaffirm the findings presented in the paper and to empirically measure the impact of natural disasters and the subsequent media coverage on the broader community's perceptions of disaster affected tourism destinations. Research that reveals the most effective marketing communications media post disaster is also needed to inform those responsible for recovery marketing campaigns and execution. Communication plays an integral role in destination recovery during and after a crisis or disaster and a comprehensive marketing communication strategy ensures DMOs can be proactive and prepared, rather than applying a cost inefficient knee jerk response, based on assumptions that may be invalid. 


\section{REFERENCES}

Armstrong, E.K \& Ritchie, B.W.(2008) The Heart Recovery Marketing Campaign: Destination recovery after a major bushfire in Australia's National capital. Journal of Travel and Tourism Marketing, 22 (2/3/4): 175-189

Baloglu, S., \& McCleary, K. W. (1999). U.S. International pleasure travelers' images of four Mediterranean destinations: A comparison of visitors and non-visitors. Journal of Travel Research, 38 (4): 144-152.

Beirman, D (2003) Restoring Tourism Destinations in Crisis: A Strategic Marketing Approach. Sydney, Allen \& Unwin

Beirman, D (2006) BEST Education Network Think Tank V Keynote Address: Marketing tourism destinations from crisis to recovery. Tourism Review International: An Interdisciplinary Journal, 10 (1/2): 7-16

Blackman, D., \& Ritchie, B.W. (2007) Tourism crisis management and organizational learning: The role of reflection in developing effective DMO crisis strategies. Journal of Travel and Tourism Marketing, 23, (2): 45-59

"Bushfire races towards Loy Yang power station". (2009, February 9). Geelong Advertiser, p.2

Carlsen, J.C \& Hughes. M. (2008) Tourism market recovery in the Maldives after the 2004 Indian Ocean Tsunami, Journal of Travel and Tourism Marketing, 23 (2): 139-149

Carlsen, J.C \& Liburd, J.L. (2007) Developing a research agenda for tourism crisis management, market recovery and communications. Journal of Travel and Tourism Marketing, 23 (2/3/4): 265- 276

Chon, K. (1991) Tourism Destination image modification process: marketing implications. Tourism Management, 12: 68-72

Cioccio, L., \& Micheal, E.J. (2007). Hazard or Disaster: Tourism management for the inevitable in North East Victoria. Tourism Management, 28: 1-11

Cohen, E., Hughes, P., \& White, P.B. (2007) Media and bushfires: A community perspective of the media during the Grampians Fires 2006. Environmental Hazards 7: 88-96

Crompton, L. (1979). Motivations for pleasure vacation. Annals of Tourism Research, 6: 408 424

Destination Gippsland Limited (2009) www.destinationgippsland.com.au, accessed April 26, 2009 
Faulkner, B. (2001) Towards a framework for tourism disaster management. Tourism Management, 22: 135-147

Fern, E.F. (1982) The use of focus groups for idea generation: the effects of group size acquaintanceship and moderator on response quantity and quality. Journal of Marketing Research, 19: 1-13

Floyd, M.F., Gibson, H., Pennington-Gray, L., \& Thapa, B. (2003) The effect of risk perceptions on intentions to travel in the aftermath of September 11, 2001. Journal of Travel and Tourism Marketing, 15 (2/3): 19-38

Gartner, W.C., \& Hunt, J.D.(1987). An analysis of state image change over a twelve-year period (1971 -1983). Journal of Travel Research 26 (2): 15-19

Gippsland fires continue to rage". Australian Broadcasting Corporation. February 92009. http://www.abc.net.au/news/stories/2009/02/09/2485927.htm. Retrieved September 30 2009

Glaesser, D. (2006) Crisis Management in the Tourism Industry, UK. Elsevier

Gross, C.W., \& Peterson, R.T. (1987) Marketing Concepts and Decision Making, West Publishing, St Paul, MN

Guthrie, J., \& Gale, P. (1991). Positioning ski areas. In New Horizons Conference Proceedings, 551-559, Calgary, University of Calgary

Hall, C. M., Timothy, D. J. and Duval, D. T. (eds) (2003) Security and tourism: Towards a new understanding? Safety and security in tourism: Relationships, management, and marketing pp. 1-18. The Haworth Hospitality Press, New York

Hall, C.M. (2002) Travel Safety, Terrorism and the Media: The Significance of the IssueAttention Cycle, Current Issues in Tourism, 5(5):, 458-466.

Hystad, P.W., \& Keller, P.C. (2007) Towards a destination tourism disaster management framework: Long lessons from a forest fire disaster, Tourism Management, 29 (1): 151-162 Jackson, N. (2009) "Blaze claims lives".(2009, February 10) Latrobe Valley Express, p 1 Jenkins, O.H. (1999) Understanding and measuring tourist destination images. International Journal of Tourism Research, 1, p1-15

Krueger, R. A., \& Casey, M. A. (2000) Focus Groups: A Practical Guide for Applied Research, 3rd ed. Thousand Oaks, CA: Sage Publications.

Lehto, X., Douglas, A.C., \& Park, J. (2007). Mediating the effects of Natural Disasters in Travel Intention, Journal of Travel and Tourism Marketing, 23 (2/3/4): 265- 276 
Leisen, B. (2001). Image segmentation: The case of a tourism destination. The Journal of Services Marketing, 15(1): 49-66.

Lepp,A., \& Gibson, H. (2003) Tourist roles, perceived risk and international tourism. Annals of Tourism Research, 30 (3): 606-624

Lincoln, Y ., \& Guba, E (1989) Fourth Generation Evaluation. Newbury Park, CA: Sage Publications.

Manfredo, M.J., Fishbein, M., Haas, G.E., \& Watson, A.E. (1990) Attitudes toward prescribed fire policies. Journal of Forestry 88: 19-23

Marshall, C., \& Rossman, G.B.(1995) Designing Qualitative Research, second Ed. USA, Sage Publications

Mayo, E.J. (1975) Tourism and national parks: A psychographical and attitudinal study. Journal of Travel Research, 14, 14-18

Morgan, D. L. (1996) Focus groups. Annual Review of Sociology, 22: 129 -152

Orosz, J.F. (1994) The use of focus groups in health care service delivery; understanding and improving the health care experience. Conference Proceedings; Qualitative Health Research Conference, Hershey, PA

Patton. M.Q. (1990) Qualitative Evaluation and Research Methods, Second Ed. USA, Sage Publications

Pearlman, D., \& Melnik, O. (2008). Hurricane Katrina's effect on the perception of New Orleans Leisure Tourists, Journal of Travel and Tourism Marketing, Vol 25 (1): 58 - 67

Pride, Elliot, Rundle-Thiele, S., et al (2006) Marketing: Core Concepts and Application: Asia Pacific Edition. Australia, Wiley \& Sons

Prideaux, Coglan \& Falco-Mammone (2007) Post crisis recovery: The case of after Cyclone Larry. Journal of Travel and Tourism Marketing, 23 (2/3/4): 265- 276

Rabiee, F. (2004) Focus - group interview and data analysis, Proceedings of the Nutrition Society 63: 655-660

Reed, J., \& Patton, V.R. (1997) Focus groups: Issues of analysis and interpretation, Journal of Advanced Nursing, 26: $765-771$

Reissman, C.K. (2002) Narrative analysis. In A.M Huberman \& M.B. Miles (eds) The Qualitative Researcher's Companian, Thousand Oaks, Sage 
Ritchie, B.W.(2008). Tourism disaster planning and management: From response to recovery reduction and readiness. Current Issues in Tourism, 11(4): 315-348

Ritchie, J., \& Spencer, L. (1994) Qualitative data analysis for applied policy research. In A. Bryman \& R.G. Burgess, (eds), Analysing Qualitative Data,(pp. 173-194). London: Routledge.

Robson, C. (1993) The Real World Research - A Resource for Social Scientists and Practitioner-researchers. Oxford: Blackwell Publications.

Roman, C. (2008) Characterising climate change vulnerability and implications for adaptation strategies in alpine regions: A case study of the tourism industry in Alpine Shire Victoria. Proceedings from the Annual Conference of the Centre for Australian Universities Tourism and Hospitality Education (CAUTHE), Gold Coast, QLD

Sanders, D. Laing, J., \& Houghton, M. (2008) Impact of Bushfires on Tourism Visitation in Alpine National Parks. Technical Report prepared for the Sustainable Tourism Cooperative Research Centre, Australia

Scott, N., Laws, E., \& Prideaux, B. (2007) Tourism crises and marketing recovery strategies, Journal of Travel and Tourism Marketing, 23 (2): 1-13

Short. J.F. (1984) The social fabric at risk: Toward the social transformation of risk analysis. American Psychological Review, 49: 711-725

Sonmez, S.F., \& Graefe, A.R. (1998) Influence of terrorism risk on foreign tourism decisions. Annals of Tourism Research, 25 (1): 112-144

Tynan C.A. \& Drayton J. (1988) Conducting focus groups - a guide for first time users. Marketing Intelligence and Planning 6: 5-9.

Volo, S. (2007) Communicating tourism crises through destination websites. Journal of Travel and Tourism Marketing, 23 (2): 83-93

Ward, Berntrand \& Brown (1991) The Comparability of Focus Group and survey results, Evaluation and Results, 15: 266 -278

Wilsons Promontory National Park, 2009: Parks Victoria, www.parkweb.vic.gov.au. Retrieved 11 January 2010. 
Figure 1

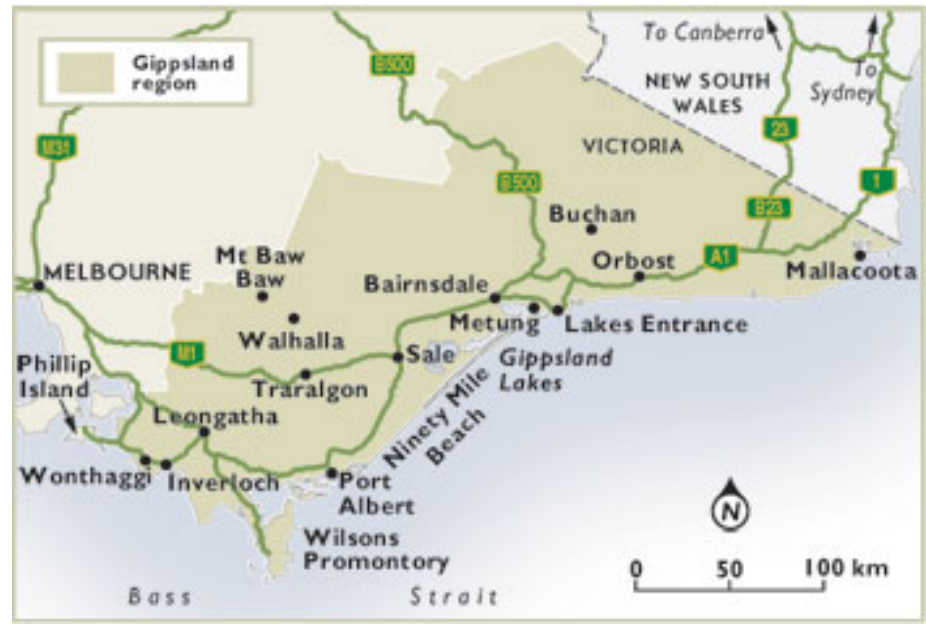

Figure 1: Map of the Victoria’s Gippsland Region: Source: Tourism Victoria web page (1 Oct 2009) 
